\title{
The Training of Writing Classroom Action Research for Teachers in SMA Negeri 1 OKI on 2022
}

\author{
Happy Fitria \\ Universitas PGRI Palembang, Indonesia \\ Email: happyfitriamufly@ univpgri-palembang.ac.id \\ Bukman Lian \\ Universitas PGRI Palembang, Indonesia \\ e-mail: drbukmanlian@ univpgri-palembang.ac.id \\ Mulyadi \\ Universitas PGRI Palembang, Indonesia \\ e-mail: mulyadi@univpgri-palembang.ac.id \\ Yessi Fitriani \\ Universitas PGRI Palembang, Indonesia \\ e-mail: yessifitriani@univpgri-palembang.ac.id \\ Nur Ahyani \\ Universitas PGRI Palembang, Indonesia \\ e-mail: nurahyani@univpgri-palembang.ac.id \\ Edi Harapan \\ Universitas PGRI Palembang, Indonesia \\ e-mail: ehara205@gmail.com \\ Achmad Wahidy \\ Universitas PGRI Palembang, Indonesia \\ e-mail: achmadwahidy@univpgri-palembang.ac.id

\section{Darwin Effendi} \\ Universitas PGRI Palembang, Indonesia \\ e-mail: $\underline{\text { darwineffendi@ univpgri-palembang.ac.id }}$
}

Article History: Received on 1 December 2021, Revised on 15 January 2022

Published on 5 February 2022

\begin{abstract}
The target and output of this training is to implement the Tridharma of Higher Education, and writing Classroom Action Research (CAR) for teachers at SMA Negeri 1 OKI. The training methods used are 1) lecturing in which the trainer explains to the trainees what and how to write and publish CAR; and 2) evidence-based learning, where training participants are invited to write together and know how to write CAR. The results obtained from this training can make participants (teachers) 1) write the background of the problem; 2) formulate the problem; 3) write a literature review; 4) writing research methodology; 5) write the results of research and discussion; 6) write conclusions, suggestions and bibliography; and 7) writing abstracts and bibliography.
\end{abstract}

Keywords: Classroom Action Research, Teachers, Training 


\section{A. Introduction}

Teachers as elements of educators who are professionals who always have to develop their profession (Law on National Education System No. 20 of 2003 and Law on Teachers and Lecturers No. 14 of 2005). One indicator of developing a profession is writing Classroom Action Research.

Writing is one thing that is still difficult to become a culture in society, and teachers are no exception. The ability of teachers to research and write is still relatively low. On the other hand, (a) teachers are required to have professional competence, namely writing scientific papers resulting from research in the field of education, (b) the guidance that has been carried out on teachers so far has not reflected their needs. In connection with that, in accordance with the requirements for skills, skills, and responsibilities in the task, as a professional position, public accountability will be enforced which refers to the fulfillment of the qualifications of the teaching profession. In addition, based on data collected by the Ministry of National Education, the majority of middle and lower school teachers were unable to move class rooms from IVa to IVb as a result of the teacher's inability to write scientific papers, which is the main requirement for moving the room. Based on the demands of teacher professionalism and overcoming the problems above, a pattern of teacher development is needed through research training and active Classroom Action Research (CAR) writing (Kristiawan et al, 2022).

For some teachers, writing CAR is considered a difficult. As a result, CAR becomes an obstacle in many ways. The ability to write CAR owned by a teacher does not come by itself, but with training and hard work to master it. It is not impossible for a teacher to write scientific papers, both classroom action research and other research based on the teacher's knowledge. Mastery of trained scientific writing will affect the quality of the educator and the institution he manages or the institution in which the teacher devotes himself. The Master of Education Management Study Program provides CAR writing training for teachers, in addition to instilling a writing culture, it also improves the ability of teachers to write and publish in journals (Jalaludin et al, 2022).

The skill of writing scientific papers which is commonly dubbed as academic writing is one of the main aspects in the world of higher education. With the ability to write a person can pour the results of his research into good scientific writing as well. Even before the research began, the skill of writing scientific paper proposals had become a demand in the academic world.

Until now, as can be read in various mass media reports, the number of publications of scientific journal articles at the international level by lecturers and researchers at universities in Indonesia is still small when compared to publications by lecturers and researchers in various countries at the ASEAN level, let alone the world level. In Indonesia, publications are mostly carried out in internal and national university journals. When measured by this status, this means that contributions and international academic debates involving Indonesian higher education institutions are still very minimal. In addition, until the end of April 2014, there were 800,000 teachers throughout Indonesia who found it difficult to fulfill the obligation to write scientific papers as a condition for promotion (Kompas, 24 April 2014, p. 12).

Based on this fact, this PTK writing training program was held. This program is expected to contribute to improving the writing skills of teachers at SMA Negeri 1 OKI (Alfaris et al, 2021; Devi et al, 2021). 


\section{B. Methods}

Writing CAR is very important in the world of education. Therefore, being skilled at writing CAR is a must for teachers at SMA Negeri 1 OKI. This activity was planned and carried out for one day. In order to carry out the activities, teachers at SMA Negeri 1 OKI were willing to provide a room along with other supporting facilities such as projectors, markers, blackboards, and others.

\section{Results and Discussion}

Universitas PGRI Palembang has three Masters Study Programs, namely Education Management Study Program, Indonesian Language Education Study Program, English Education Study Program therefore the required expertise has been met. In the implementation of this Community Service activity, the team is a permanent lecturer of Three Masters Study Programs at the Postgraduate Program at Universitas PGRI Palembang. The team that has been prepared provides full service to partner school managers in the form of CAR writing training. To realize these activities, an implementation team was formed. The following table is a description of the community service implementation team.

Table 1. Description of the Community Service Implementing Activity Team

\begin{tabular}{|c|c|c|c|}
\hline No & Name and Title of Proposing Team & Type of Expertise & Tasks of the Proposing Team \\
\hline 1 & Dr. Happy Fitria, M.Pd. & Education & Writing Problem Background \\
\hline 2 & Dr. H. Bukman Lian., M.M.,M.Si. & Management & \\
\hline 3. & Dr. Mulyadi, M.A. & $\begin{array}{l}\text { English Language } \\
\text { Education }\end{array}$ & Abstract Writing \\
\hline 4. & Dr. Yessi Fitriani, M.Pd. & $\begin{array}{l}\text { Indonesian } \\
\text { Language } \\
\text { Education }\end{array}$ & Literature Review Writing \\
\hline 4. & Dr. Nur Ahyani, M.Pd & $\begin{array}{l}\text { Education } \\
\text { Management }\end{array}$ & Research Methodology Writing \\
\hline 6. & Dr. H. Edi Harapan, M.Pd. & Education & Writing Research Results and \\
\hline 7. & Dr. Achmad Wahidy, M.Pd. & $\begin{array}{l}\text { Management and } \\
\text { Indonesian } \\
\text { Language } \\
\text { Education }\end{array}$ & Discussion \\
\hline 8. & Dr. Darwin Effendi, M.Pd. & $\begin{array}{l}\text { Indonesian } \\
\text { Language } \\
\text { Education }\end{array}$ & $\begin{array}{l}\text { Writing Conclusions, } \\
\text { Suggestions and Bibliography }\end{array}$ \\
\hline
\end{tabular}

The CAR writing training for SMA Negeri 1 OKI Teachers was held in January 2022. The result of this service activity is to provide understanding and skills for teachers at SMA Negeri $1 \mathrm{OKI}$ in writing CAR. In general, the target and output that will result from this activity is that teachers can write CAR. In particular, the targets and outcomes of this activity for teachers at SMA Negeri 1 OKI 1) write the background of the problem; 2) formulate the problem; 3) write a literature review; 4) writing research methodology; 5) write the results of research and discussion; 6) write conclusions, suggestions and bibliography; and 7) writing abstracts and bibliography (Nitiasih, 2010; Wiriaatmaja, 2005; Badu, 2012; Martono, 2009). 


\section{Conclusion}

Based on the results, it concludes that the class management of teachers in the implementation of the learning process had been considered good. The obstacles were lack of skill in new technologies.

\section{E. Acknowledgement}

Thank to Rector Universitas PGRI Palembang, Director of Postgraduate Program and Chief of LPPKM Universitas PGRI Palembang who have supported us to do this valuable project.

\section{References}

Alfaris, M. M., Sauri, S., \& Gaffar, M. A. . (2021). Guidance and Counseling Management on Personal, Social, Learning and Career Development of SMK 19 Bandung Students During Covid-19 Pandemics. Journal of Social Work and Science Education, 2(2), 169176. https://doi.org/10.52690/jswse.v2i2.244

Badu, A. M. (2012). Pengembangan Model Pelatihan Pendampingan Dalam Rangka Peningkatan Kompetensi Pendamping Pada Kelompok Usaha Konveksi di Kota Gorontalo [Development of Mentoring Training Models in the Context of Enhancing Competency of Facilitators in Convection Business Groups in Gorontalo City]. Thesis. Bandung: Program Pascasarjana UPI.

Devi, D., Harapan, E., \& Wardiah, D. (2021). The Implementation of Principal's Supervision in SD Negeri Tungkal Ilir Banyuasin (Teacher's Competency Development Study). Journal of Social Work and Science Education, 2(1), 60-68. https://doi.org/10.52690/jswse.v2i1.206

Jalaludin, J., Novita, M., \& Asvio, N. (2022). Print-Based Media in Methodology Course of Classroom Action Research. Journal of Social Work and Science Education, 2(3), 208218. https://doi.org/10.52690/jswse.v2i3.250

Kompas. (24 April 2014). Guru Sulit Penuhi Syarat Karya Tulis [Teachers find it difficult to fulfill writing requirements].

Kristiawan, M., Nipriansyah, N., Yanti, F. A., \& Viona, E. (2022). Penulisan dan Publikasi Penelitian Tindakan Kelas Bagi Guru [Classroom Action Research Writing and Publication for Teachers]. Jurnal Basicedu, 6(1), 95-101.

Law on National Education System No. 20 of 2003

Law on Teachers and Lecturers No. 14 of 2005

Martono, B. (2009). Optimalisasi Kemampuan Penyusunan Proposal Penelitian Tindakan Kelas (PTK) Melalui Metode Tutorial bagi Guru SMK Peserta Diklat di PPPPTK BOE Malang [Optimizing the Ability to Prepare Classroom Action Research (CAR) Proposals 
Journal of Social Work and Science Education

Volume 3 (1) 2022

E-ISSN: 2723-6919 P-ISSN: 2746-0827

through Tutorial Methods for Vocational Teachers Training Participants at PPPPTK BOE Malang]. Jurnal Online PPPPTK BOE.

Nitiasih, P., Padmadewi, N. N., \& Sutama, L. P. (2010). Pengembangan Model Pelatihan Penelitian Tindakan Kelas Refleksi Berbasis Kompetensi [Competency Based Reflection Class Action Research Training Model Development]. Jurnal Penelitian dan Pengembangan Pendidikan, 4 (3) 252-266.

Wiriaatmadja, R. (2005). Metode Penelitian Tindakan Kelas Untuk Meningkatkan Kinerja Guru dan Dosen [Classroom Action Research Methods to Improve Teacher and Lecturer Performance]. Bandung: Remaja Rosdakarya 